\title{
Effect of Storage on Viability of Fusarium Head Blight-Affected Spring Wheat Seed
}

\author{
J. Gilbert, A. Tekauz, and S. M. Woods, Agriculture and Agri-Food Canada, Cereal Research Centre, 195 Dafoe \\ Road, Winnipeg, Manitoba, Canada R3T 2M9
}

\begin{abstract}
Gilbert, J., Tekauz, A., and Woods, S. M. 1997. Effect of storage on viability of Fusarium head blight-affected spring wheat seed. Plant Dis. 81:159-162.

The effects of storage temperature and duration on germination, emergence, and vigor of Fusarium head blight-affected seed were studied in the spring wheat cvs. Glenlea and Roblin. Seed was stored at $-10,2.5,10$, or $20^{\circ} \mathrm{C}$. Germination was assessed at cold $\left(5^{\circ} \mathrm{C}\right)$ and moderate $20 / 15^{\circ} \mathrm{C}$ for $16 / 8 \mathrm{~h}$ daily) temperatures following $0,8,16$, and 24 weeks of storage. Emergence from a soilless mix was counted 10 days after planting. Vigor was assessed following germination by measuring root and shoot lengths and in emerged plants by determining dry shoot weights. Germination after storage at the three colder temperatures decreased with length of storage, but storage at $20^{\circ} \mathrm{C}$ did not affect germination. Overall, germination of Fusariumaffected seed at moderate temperatures was significantly lower than for healthy seed. Germination of infected seed at $5^{\circ} \mathrm{C}$ was better than at moderate temperatures, probably due to lack of fungal activity at low temperatures. Seed treatment with Vitaflo 280 improved germination, but not emergence, of infected seed. However, roots from treated infected seed were shorter than from untreated seed. Emergence of infected seeds was better after storage at 10 and $20^{\circ} \mathrm{C}$ than at -10 and $2.5^{\circ} \mathrm{C}$. Storage temperature did not significantly affect vigor. Dry shoot weight at 14 days was lower after storage at -10 than at $20^{\circ} \mathrm{C}$.
\end{abstract}

Additional keywords: Fusarium graminearum, Triticum aestivum

Fusarium graminearum (Schwabe, Group II) is the principle cause of Fusarium head blight (scab) in the small-grain cereals in southern Manitoba. This area experienced severe Fusarium head blight epidemics in 1993 and 1994 following above-average rainfall at flowering. Losses due to reduced yield and quality were estimated at \$CDN 75 million in 1993 (12). Seed affected by the epidemic had reduced germination and produced seedlings with poor emergence and vigor (11).

Storage environment and duration influence germination in cereal grains $(19,20)$. The germination of healthy wheat seed stored in a dry, unheated room was reduced by only $5 \%$ after 10 to 12 years $(19,20)$. Bergstrom (3) observed that germination of seed infected with $F$. graminearum actually improved after several months of storage and speculated that the fungus survived poorly in the seed. Gilbert and Tekauz (11) likewise reported that emergence of seedlings grown from Fusarium-affected seed

Corresponding author: J. Gilbert

E-mail jgilbert@em.agr.ca

Contribution No. 1664, Agriculture and Agri-food Canada, Cereal Research Centre, Winnipeg.

Accepted for publication 16 October 1996.

Publication no. D-1996-1104-04R

(C) 1997 Department of Agriculture and AgriFood, Government of Canada was higher 6 months after harvest than it was after 2 months.

In the Canadian prairies, seed of small grains is usually stored in outdoor granaries, and the minimum temperature that the seed is subjected to in the grain bulk varies depending on the ambient air temperatures and the shape and size of the bin (15). Low temperatures in the grain bulk suppress insect activity and reduce fungal metabolism in grain harvested at low moisture levels $(9,14)$.

The objective of the present study was to determine the effects of storage temperature and duration on germination, emergence, and vigor of spring wheat seed infected with $F$. graminearum.

\section{MATERIALS AND METHODS}

Four Fusarium head blight-affected seed lots of $3 \mathrm{~kg}$ each of the hard red spring wheat (Triticum aestivum L.) cvs. Glenlea and Roblin were obtained approximately 6 weeks after their harvest by commercial seed producers in southern Manitoba in 1994. Seed of Glenlea from 1990 and of Roblin from 1992, years when the incidence of head blight was very low, served as Fusarium-free controls. Half the grain from each seed lot was treated with Vitaflo 280 (carbathiin and thiram at 0.55 and 0.49 $\mathrm{g}$ a.i./kg seed, respectively, Gustafson, Uniroyal Chemical Ltd.). One hundred seeds of each seed lot were surface sterilized ( 1 min in $0.3 \%$ sodium hypochlorite) and placed on potato dextrose agar under continuous cool white light for 4 days to determine the Fusarium species present. Grain was kept at ambient temperature for 8 weeks before the storage experiments began. Seed was stored at constant temperatures $-10,2.5,10$, and $20^{\circ} \mathrm{C}$ for 24 weeks in brown paper bags submerged in a larger bulk of grain.

Germination. After $0,8,16$, and 24 weeks of storage at the specified temperatures, subsamples of approximately $5 \mathrm{~g}$ were removed, germinated at $5^{\circ} \mathrm{C}$ (low temperature, "cold-germ vigor test") and assessed after 12 days, and germinated at $20^{\circ} \mathrm{C}$ for $16 \mathrm{~h}$ and $15^{\circ} \mathrm{C}$ for $8 \mathrm{~h}$ daily (moderate temperatures) and evaluated after 8 days, as prescribed by the Association of Official Seed Analysts (1). One hundred seeds for each duration/storage temperature treatment by seed lot combination were germinated on moist filter paper in three, $15-\mathrm{cm}$, plastic petri dishes. At week 0 there were two replications.

Emergence. After the 24-week storage period all seed was maintained at $-20^{\circ} \mathrm{C}$ for 8 weeks, until emergence was tested. For each treatment by seed lot combination 32 seeds were sown in a soilless medium (Metromix 220, Grace Horticultural Products, Ajax, ON, Canada), one seed per plastic cell (Multi-Pot \#5-104, cavity volume 49 $\mathrm{cm}^{3}$, Stuewe and Sons, Inc., Corvallis, OR). Emergence tests were conducted in a glass house at $20 \pm 2^{\circ} \mathrm{C}$ and with a 16-h photoperiod. The three replications for emergence were assessed at 14 days.

Vigor. After emergence levels were determined, 10 randomly selected plants were removed from each replicate. Roots were discarded and shoots were dried at $30^{\circ} \mathrm{C}$ for $24 \mathrm{~h}$, cooled to room temperature, and weighed. Shoot weights for 35-day-old plants were obtained in the same way. After 10 weeks of storage, 100 seeds for each treatment by seed lot combination were germinated under the conditions outlined above for 8 and 12 days at moderate and low germination temperatures, respectively, and the root and shoot lengths were measured.

Statistical analysis. The entire experiment was a split-split plot design with infection (control or infected) applied to main plots (seed lots), and fungicide treatment (treated or untreated) applied to subplots (halves of seed lots). The 13 storage treatments (temperature and duration combinations) and germination temperature were applied to samples (sub-subplots). 
Interactions were included in preliminary analyses, but those that showed little importance were omitted from later analyses. In particular, no interactions between storage treatment and the initial factors (infection and fungicide treatment) were included in the final analyses.

To study the effect of storage treatment on germination, analyses at low and moderate germination temperatures were done separately. The effect of storage treatment component and lack of fit. Arcsine-transformed germination was regressed on weeks of storage (excluding week 0 ) with a separate slope for each temperature and a common intercept. For germination at moderate temperatures, this was followed by a similar analysis of the infected seed, to compare the rates of decline in germination at the four storage temperatures. The effect of germination temperature after 24 weeks of storage was tested for different storage temperatures or fungicide treatments. Healthy and infected seed were analyzed separately.

Mean root and shoot length by seed lot, fungicide treatment, and storage temperature were analyzed separately for each germination temperature, to test the effects of storage and initial factors. No transformation of the data was needed. Emergence was partitioned into a linear regression

(untransformed) and dry shoot mass (square root transformed) at 14 and 35 days were analyzed with replicate as a fixed effect and main plots and subplots (as above) as random effects. Healthy and infected seed were analyzed separately.

SAS (SAS Institute Inc., Cary, NC) was used for all analyses. The Mixed procedure was used for analysis of variance; comparisons were made with contrasts when the $F$ test was significant. The GLM procedure was used to generate the sums of squares in Table 1.

\section{RESULTS}

No Fusarium species grew from healthy seed. F. graminearum was found in $27 \%$ of the seed of the four samples of cv. Glenlea (range 17 to $39 \%$ ), and in $30 \%$ of cv. Roblin (range 19 to $45 \%$ ). Five other Fusarium spp. were isolated from this seed, but all less than $0.02 \%$.

Germination. Initial germination at low temperature at week 0 for all seed samples ranged from 85 to $92 \%$; at moderate temperatures the range was 75 to $97 \%$. With one exception, after 24 weeks at $-10^{\circ} \mathrm{C}$, germination of healthy seed at moderate temperatures was greater than $90 \%$.

For germination at moderate temperatures, storage temperature and duration were highly significant and were explained

Table 1. Analysis of variance of effect of storage temperature and duration, Fusarium head blight infection, and fungicide treatment on germination of seed of spring wheat cultivars at $20 / 15^{\circ} \mathrm{C}$ for $16 / 8 \mathrm{~h}$ (moderate) and $5^{\circ} \mathrm{C}$ (low) temperatures

\begin{tabular}{|c|c|c|c|c|c|}
\hline \multirow[b]{3}{*}{ Source of variation } & \multirow[b]{3}{*}{ df } & \multicolumn{4}{|c|}{ Germination temperature } \\
\hline & & \multicolumn{2}{|c|}{ Moderate } & \multicolumn{2}{|c|}{ Low } \\
\hline & & SS & $F$ ratio & SS & $F$ ratio \\
\hline Infection & 1 & 2.1451 & $13.59 * * \mathrm{w}$ & 0.0845 & 0.61 \\
\hline Error A & 8 & 1.2632 & & 1.1171 & \\
\hline Fungicide treatment (infection) & 2 & 0.8418 & $43.20^{* *}$ & 0.0924 & $5.60^{*}$ \\
\hline Healthy: T vs $U^{x}$ & 1 & 0.0454 & 4.66 & 0.0557 & $6.75^{*}$ \\
\hline Infected: T vs U & 1 & 0.7964 & $81.74 * *$ & 0.0367 & 4.44 \\
\hline Error B & 8 & 0.0779 & & 0.0661 & \\
\hline Storage treatment ${ }^{\mathrm{y}}$ & 12 & 0.6152 & $8.84 * *$ & 0.2106 & $3.78 * *$ \\
\hline Regression $^{\mathrm{z}}$ & 5 & 0.5863 & $20.23 * *$ & 0.0348 & 1.50 \\
\hline Lack of fit & 7 & 0.0289 & 0.71 & 0.1758 & $5.40 * *$ \\
\hline Error C & 248 & 1.4377 & & 1.1524 & \\
\hline
\end{tabular}

w**, * significant at $P<0.01$, and $P<0.05$, respectively.

$\mathrm{x}$ T vs $\mathrm{U}=$ Treated (Vitaflo 280) versus Untreated.

${ }^{\text {y }}$ Germination tested at $0,8,16$, and 24 weeks after storage at $-10,2.5,10.0$, or $20.0^{\circ} \mathrm{C}$, respectively.

${ }^{\mathrm{z}}$ Regression: the fit of four separate lines of transformed germination vs time with a common intercept.

Table 2. Overall means (back transformed from arcsine transformed) of germination of healthy and Fusarium-affected spring wheat seed averaged over 13 storage temperature/duration treatments at two temperatures

\begin{tabular}{lccccc}
\hline & \multicolumn{4}{c}{ Germination temperature } \\
\cline { 2 - 3 } \cline { 5 - 6 } Treatment & \multicolumn{2}{c}{ Moderate $^{\mathbf{x}}$} & & Low $^{\mathbf{y}}$ \\
\cline { 2 - 3 } \cline { 5 - 6 } & Healthy & Infected & & Healthy & Infected \\
\hline Treated $^{\mathrm{z}}$ & 96 & 86 & & 86 & 86 \\
Untreated & 93 & 76 & & 90 & 85 \\
Mean & 95 & 81 & & 88 & 86 \\
\hline
\end{tabular}

${ }^{\mathrm{x}}$ After 8 days at $20 / 15^{\circ} \mathrm{C}$ for $16 / 8$ h daily.

y After 12 days at $5^{\circ} \mathrm{C}$.

z Treated with Vitaflo 280. by a regression model (Table 1). Overall germination of infected seed was lower than that of healthy seed (Table 2). Treated infected seed had higher germination levels than untreated infected seed. Fungicide treatment did not affect germination of healthy seed. By contrast, for germination at $5^{\circ} \mathrm{C}$ storage, treatment was significant but no pattern could be discerned (Table 1). There was no overall difference in germination between infected and healthy seed (Table 2). Treated healthy seed had lower germination than untreated healthy seed but there was no difference in the infected seed.

At moderate temperatures, germination of infected seed stored at $-10,2.5$, and $10.0^{\circ} \mathrm{C}$ declined between 8 and 24 weeks. The rate of decline increased with lower storage temperature (Fig. 1).

After 24 weeks of storage, infected seed had lower germination at moderate temperatures than at $5^{\circ} \mathrm{C}$, but the difference lessened as storage temperature increased (Fig. 2B). There was no difference after storage at $20^{\circ} \mathrm{C}$. Germination at $5^{\circ} \mathrm{C}$ was unaffected by storage temperature, whereas germination at moderate temperatures increased with storage temperature. Germination of healthy seed was higher at moderate temperatures than at $5^{\circ} \mathrm{C}$, and seemed to be less affected by storage temperature (Fig. 2A). At $5^{\circ} \mathrm{C}$ there was little fungal growth from infected seed, whereas at moderate temperatures growth was profuse.

Germination of untreated infected seed at moderate temperatures was low (Fig. 3). Either treatment with a fungicide or germinating the seed at a lower temperature improved germination. Healthy fungicidetreated seed germinated much better at moderate temperatures than at $5^{\circ} \mathrm{C}$. Germination of healthy untreated seed was unaffected by germination temperature.

Emergence. Fungicide treatment was not a significant factor affecting emergence. Seed stored at -10 and $2.5^{\circ} \mathrm{C}$ had lower emergence than seed stored at 10 or $20^{\circ} \mathrm{C}$. The effect was significant for infected seed (Fig. 4).

Vigor. Storage temperature was not a significant factor in determining root and shoot length of plantlets germinated after 10 weeks of storage. Roots and shoots from healthy seed, germinated at moderate temperatures, were significantly longer than those from infected seed (Table 3 ). When germinated at $5^{\circ} \mathrm{C}$ roots produced from healthy treated seed were shorter than those from infected seed. The same trend was observed in shoots developing from healthy seed (Table 3). Dry shoot weight of 14-day-old seedlings grown from infected seed increased slightly with increasing storage temperature. There were no significant differences in 35-day-old seedlings. Fungicide treatment had no effect. Dry shoot weight from healthy seed showed no response to storage temperature or fungicide treatment. 


\section{DISCUSSION}

Effects of storage temperature and duration of storage on germination of Fusarium-affected wheat seed were highly significant. More wheat seed germinated at moderate temperatures after storage at $20^{\circ} \mathrm{C}$ than after storage at lower temperatures. Seed stored at lower temperatures exhibited a progressive decline in ability to germinate during 24 weeks of storage. In contrast, storage temperature did not significantly affect germination levels when tested at $5^{\circ} \mathrm{C}$.

Healthy and infected seed responded differently to germination temperature. These results confirmed the findings of an earlier study in which healthy seed of hard red spring wheat cultivars germinated better at moderate temperatures, while Fusariumaffected seed germinated better at $5^{\circ} \mathrm{C}$ (11). Only limited fungal growth was evident on or around seed germinated at low temperature, supporting observations that seed-borne $F$. graminearum requires temperatures higher than $15^{\circ} \mathrm{C}$ for vigorous growth (13). Bergstrom (3) attributed improved germination of Fusarium-affected seed to poor survival of Fusarium after several months of storage. In the present study, mean germination of infected seed stored at $20^{\circ} \mathrm{C}$ was not different after 24 weeks, possibly because initial germination levels were already over $80 \%$.

At moderate temperatures, fungicide treatment improved germination of both healthy and infected seed, but at $5^{\circ} \mathrm{C}$ healthy seed germinated at significantly lower levels. This effect has also been noted in earlier studies (11). Poorest germination occurred in untreated infected seed germi- nated at moderate temperatures that are optimum for growth of $F$. graminearum (8).

Emergence of infected seed stored for 24 weeks at 10 and $20^{\circ} \mathrm{C}$ was higher than for seed stored at -10 and $2.5^{\circ} \mathrm{C}$ and confirmed an earlier report that emergence of Fusarium-affected seed improved after storage at room temperature for 4 months (11). Fungicide treatment had no effect on emergence in this study. Other studies have reported improved emergence after fungicide treatment of Fusarium-affected seed $(11,16-18)$, but contradictory results on the efficacy of seed dressings also have been found $(6,7,21)$. Buechley and Shaner (6) and Buechley et al. (7) used seed of cv. Caldwell in which $8 \%$ of the kernels were "Fusarium damaged," and found that fungicide seed treatment did not improve stands significantly over those from untreated controls. In one case, yields of untreated plots equaled or surpassed those from fungicide-treated plots. However, as only $8 \%$ of the seed was affected, and 1 or 2 years elapsed between harvest and testing, little Fusarium may have survived. Bergstrom et al. $(4,5)$ also showed that agronomically acceptable yields were obtained from Fusarium-affected seed lots when they were not treated with fungicide.

Percent emergence for infected seed was generally equal to, or higher than, percent germination, especially following storage at -10 and $2.5^{\circ} \mathrm{C}$. These results are different from those of a 1993 study in which germination of Fusarium-affected seed was $14 \%$ lower than emergence (11). Dickson (8) showed that moderate $\left(12\right.$ to $\left.28^{\circ} \mathrm{C}\right)$ soil temperatures were the most important factor determining seedling blight of Fusari- $u m$-affected seed, but, in addition, low soil moisture favored blighting of wheat even at low soil temperatures. In the 1993 study the soil mix was clay loam, sand, and Zorb-All (Aimcor, Deerfield, IL) in a 4:1:1 volume ratio that drained well. In the present study, a soilless mix that maintained high moisture levels was used and may have favored emergence of affected seed. Storage temperature had little effect on vigor of seedlings from infected seed, but fungicide treatment appeared to have a phytotoxic effect when seed was germinated at low temperature. Roots from treated infected seed were shorter than from untreated infected seed. These results support the findings of our earlier study in which root weight of treated Fusariumaffected seed was less than that of untreated infected seed (11).

Ganguli and Sen-Mandi (10) have shown that the scutellum plays an important role during imbibition leading to germination. Amylase activity in the scutellum and visible signs of germination are well correlated. The endospermic reserves of the aleurone layer hydrolyse only when the germinating seedling reaches the rapid growth stage. Microscopic examination of wheat seed that was only lightly infected with $F$. graminearum, but exhibited impaired germination, revealed extensive fungal invasion of the scutellum and embryonic axis during imbibition (2). The reduction in germination of seed stored at $-10.0,2.5$, and $10.0^{\circ} \mathrm{C}$ over time as found in the present study indicates that the fungus survives well at colder storage temperatures, and also that infected seed appears to lose viability more rapidly at

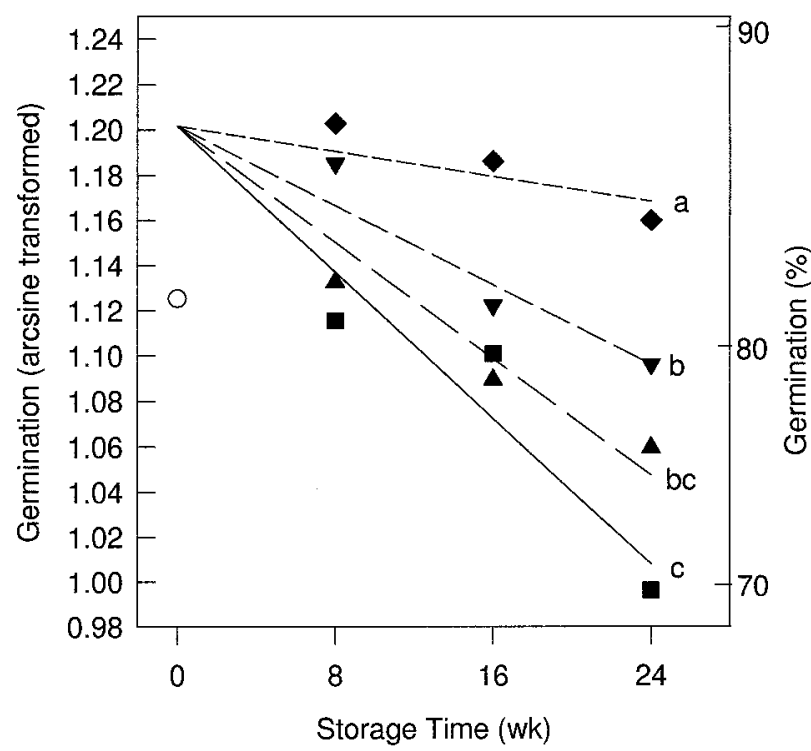

Fig. 1. Linear effect of time on mean germination (arcsine-transformed data) at moderate temperatures of Fusarium-affected spring wheat seed stored at $-10^{\circ} \mathrm{C}(\boldsymbol{\nabla}$, solid line $), 2.5^{\circ} \mathrm{C}(\boldsymbol{\Delta}$, broken line $), 10^{\circ} \mathrm{C}(\boldsymbol{\nabla}$, broken line), or $20^{\circ} \mathrm{C}(\boldsymbol{\bullet}$, broken line), with a common intercept and separate slopes. Mean of treated and untreated seed. (O) represents mean of two replicates of pre-storage germination, not used in the regression. Slopes followed by a letter in common are not significantly different at $P<$ $0.05)$.

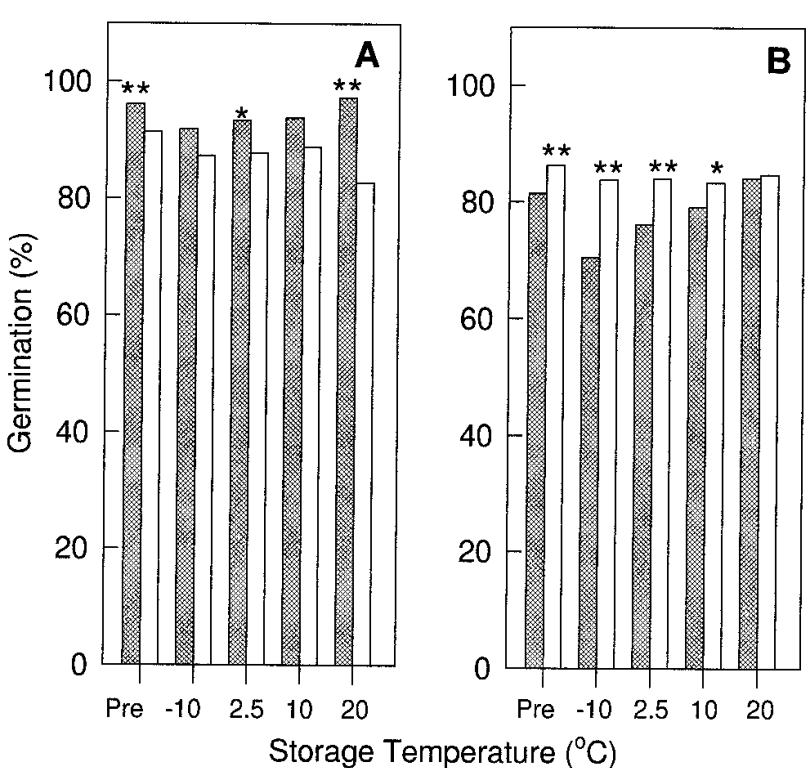

Fig. 2. Mean percent germination after 8 days at moderate temperatures $\left(20 / 15^{\circ} \mathrm{C}\right.$ for $16 / 8 \mathrm{~h}$ daily, shaded bars) and 12 days at $5^{\circ} \mathrm{C}$ (unshaded bars) of (A) healthy and (B) Fusarium-affected spring wheat seed following 24 weeks of storage at different temperatures. Back-transformed means of arcsine-transformed data. $*, * *$ indicate a significant difference between adjacent bars at $P<0.05$ and $P<0.01$, respectively. 


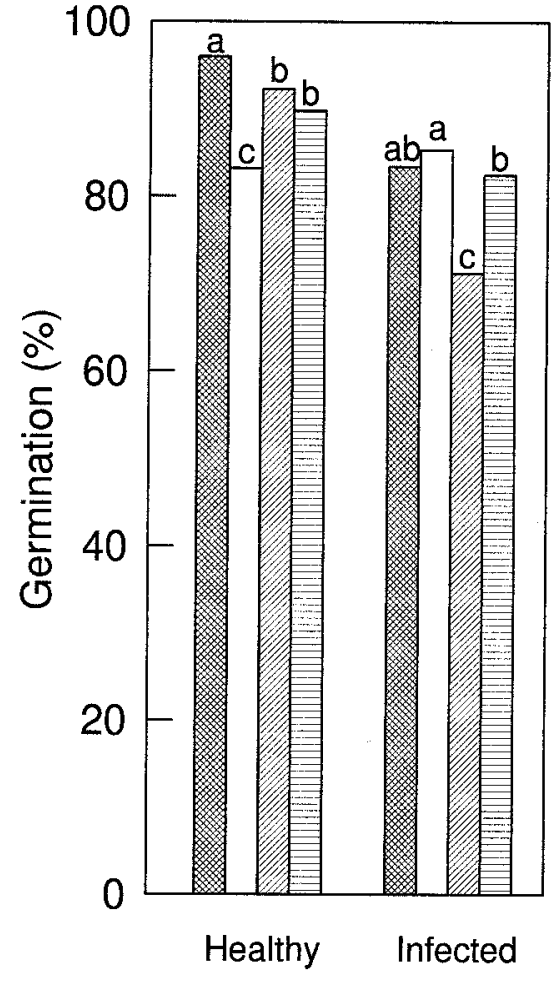

Fig. 3. Mean percent germination after 8 days at moderate temperatures $\left(20 / 15^{\circ} \mathrm{C}\right.$ for $16 / 8 \mathrm{~h}$ daily) and 12 days at low temperature $\left(5^{\circ} \mathrm{C}\right)$ of treated and untreated, healthy and Fusariumaffected spring wheat seed, following 24 weeks of storage at different temperatures. Backtransformed means of arcsine-transformed data. Moderate temperatures and treated with Vitaflo 280 (cross-hatched bars), low temperature and treated with Vitaflo 280 (unshaded bars), moderate temperatures, untreated (diagonally shaded), and low temperatures, untreated (horizontally shaded). Bars within groups with letters in common are not significantly different at $P<0.05$.

colder temperatures as evidenced by the decline in germination levels with time. By contrast, it is conjectured that viability of Fusarium-affected seed stored at $20^{\circ} \mathrm{C} \mathrm{im-}$ proved over time because of diminishing pathogen survival.

On the Canadian prairies storage of grain at low temperatures is generally recommended. Jayas et al. (15) recommended the use of small-diameter, tall grain bins that expose grain even at the bin center to below freezing temperatures. This generally prevents survival and/or multiplication of mite and insect pests and of fungal saprophytes. Comparing bins of 15, 12, 9, 6, and $3 \mathrm{~m}$ in diameter, they found temperatures after 180 days of storage were 17, 17, 12,7 , and $-13^{\circ} \mathrm{C}$, respectively. The lower temperatures in the smaller bins likely would promote survival of Fusarium, as suggested from our study.

It appears that the cold temperatures recommended for safe grain storage and control of fungal saprophytes, insect pests, and mites are conducive to the survival $F$. graminearum and may reduce the viability of wheat seed affected by this pathogen.

Table 3. Means of root and shoot lengths (mm) of seedlings from Fusarium-affected seed germinated at $20 / 15^{\circ} \mathrm{C}$ for $16 / 8 \mathrm{~h}$ (moderate) and $5^{\circ} \mathrm{C}$ (low) temperatures for 8 and 12 days, respectively

\begin{tabular}{|c|c|c|c|c|}
\hline \multirow[b]{3}{*}{ Treatment } & \multicolumn{4}{|c|}{ Germination temperature } \\
\hline & \multicolumn{2}{|c|}{ Moderate } & \multicolumn{2}{|c|}{ Low } \\
\hline & Roots & Shoots & Roots & Shoots \\
\hline Healthy treated ${ }^{y}$ & $78.9 \mathrm{a}^{\mathrm{z}}$ & $57.1 \mathrm{a}$ & $12.9 \mathrm{c}$ & 3.4 \\
\hline Healthy untreated & $71.6 \mathrm{a}$ & $40.7 \mathrm{~b}$ & $14.8 \mathrm{bc}$ & 3.7 \\
\hline Infected treated & $51.8 \mathrm{~b}$ & $26.4 \mathrm{c}$ & $16.4 \mathrm{~b}$ & 3.7 \\
\hline Infected untreated & $53.4 \mathrm{~b}$ & $23.5 \mathrm{c}$ & $18.8 \mathrm{a}$ & 3.9 \\
\hline
\end{tabular}

y Seed treated with Vitaflo 280.

${ }^{\mathrm{z}}$ Means within columns with a letter in common, or no letter, are not significantly different at $P<$ 0.05 .

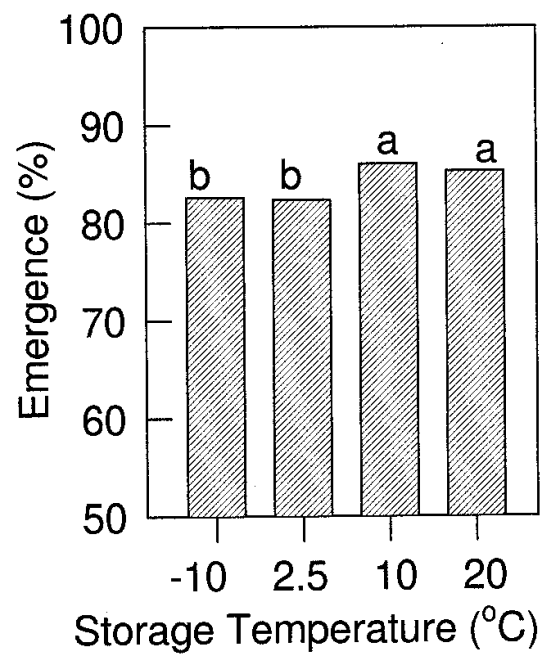

Fig. 4. Mean percent emergence of Fusariumaffected spring wheat seed after 24 weeks of storage at different temperatures. Bars with the same letter are not significantly different at $P<0.05$.

This occurred even after the relatively short ( 24 weeks) storage period tested, representative of on-farm storage between harvest and spring seeding. Seed stored in this manner, and known or suspected to have Fusarium contamination, likely should be treated with an effective fungicide prior to sowing, to ensure high levels of germination and emergence.

\section{ACKNOWLEDGMENTS}

The technical assistance of R. Kaethler, U. Kromer, and E. Mueller is gratefully acknowledged.

\section{LITERATURE CITED}

1. Association of Official Seed Analysts. 1981. Rules for testing seeds. J. Seed Technol. 3:50.

2. Bechtel, D. B., Kaleikau, L. A., Gaines, R. L., and Seitz, L. M. 1985. The effects of Fusarium graminearum infection on wheat kernels. Cereal Chem. 62:191-197.

3. Bergstrom, G. 1993. Scab (Fusarium Head Blight). Pages 83-93 in: Seed-borne diseases and seed health testing of wheat. S. B. Mathur and B. M. Cunfer, eds. Danish Gov. Inst. Seed Pathol. Develop. Countries. Jordbrugsforlaget, Frederiksberg, Denmark.

4. Bergstrom, G. C., Kalb, D. W., Harman, G. E., Samimy, C., and Sorrells, M. E. 1988. Effect of seed treatments on agronomic performance of soft white winter wheat from "scabby" seed, 1987. Fungic. Nematic. Tests 43:239.

5. Bergstrom, G. C., Kalb, D. W., Harman, G. E., Samimy, C., and Sorrells, M. E. 1989. Effect of seed treatments on agronomic performance of soft red winter wheat from "scabby" seed, 1988. Fungic. Nematic. Tests 44:218.

6. Buechley, G., and Shaner, G. 1988. Effect of seed treatment on stand establishment from scabby seed, 1987. American Phytopathological Society. Fungic. Nematicide Tests 43:241.

7. Buechley, G., Lehman, J., and Shaner, G. 1989. Effect of seed treatment on stand establishment from scabby seed, 1988. Fungic. Nematic. Tests 44:220.

8. Dickson, J. G. 1923. Influence of soil temperature and moisture on the development of the seedlingblight of wheat and corn caused by Gibberella saubineti. J. Agric. Res. 23: 837-882.

9. Fields, P. G. 1992. The control of storedproduct insects with extreme temperatures. J. Stored Prod. Res. 28:89-118.

10. Ganguli, S., and Sen-Mandi, S. 1993. Effects of ageing on amylase activity and scutellar cell structure during imbibition in wheat seed. Ann. Bot. 71:411-416.

11. Gilbert, J., and Tekauz, A. 1995. Effects of Fusarium head blight and seed treatment on germination, emergence, and seedling vigor of spring wheat. Can. J. Plant Pathol. 17:252-259.

12. Gilbert, J., Tekauz, A., Mueller, E., and Kromer, U. 1994. Occurrence of Fusarium head blight in Manitoba in 1993. Can. Plant Dis. Surv. 74:77-78.

13. Halfon-Meiri, Al, Kulik, M. M., and Schoen, J. F. 1979. Studies on Gibberella zeae carried by wheat seeds produced in the Mid-Atlantic region of the United States. Seed Sci. Technol. 7:439-448.

14. Hyde, M. B., and Burrell, N. J. 1973. Some recent aspects of grain storage technology. Pages 313-341 in: Grain Storage: Part of a System. R. N. Sinha and W. E. Muir, eds. Avi Publishing, Westport, CT.

15. Jayas, D. S., Alagusundaram, D., Shunmugam, G., Muir, W. E., and White, N. D. G 1994. Simulated temperatures of stored grain bulks. Can. Agric. Eng. 36:239-245.

16. Johnston, H. W., and Cobb, B. 1981. Influence of seed treatment on performance of spring wheat. Page 289 in: Pestic. Res. Rep. Cat. No. A41-14/1980.

17. McMullen, M. P., and Stack, R. W. 1987. Improving wheat and durum seedling stands and vigour by fungicide seed treatments. N.D. Farm Res. 44:13-15.

18. Martin, R. A., and Johnston, H. W. 1982. Effects and control of Fusarium diseases of cereal grains in the Atlantic Provinces. Can. J. Plant Pathol. 4:210-216.

19. Robertson, D. W., and Lute, A. M. 1937. Germination of seed of farm crops in Colorado after storage for various periods of years. J. Am. Soc. Agron. 29:822-834.

20. Robertson, D. W., Lute, A. M., and Kroeger, H. 1943. Germination of 20-year-old wheat, oats, barley, corn, rye, sorghum and soybeans. J. Am. Soc. Agron. 35:786-795.

21. Uoti, J. 1979. Study of control of seed-borne Fusarium in cereals. Ann. Agric. Fenn. 18: 149-153. 